\title{
Community dynamics of tropical reef fishes: local patterns between latitudes
}

\author{
M. Julian Caley* \\ Department of Marine Biology, James Cook University, Townsville, Queensland 4811, Australia
}

\begin{abstract}
Latitudinal variation in the dynamics of biological communities is among the least addressed and understood topics of modern ecology. Here, I examine the dynamics of coral-reef fish communities inhabiting small rubble patches at 2 locations separated by approximately $9^{\circ}$ of latitude (One Tree Island and Lizard Island) on Australia's Great Barrier Reef. This sampling program ran simultaneously at the 2 locations using identical census methods, sampled over 16 mo and included 2 summer recruitment seasons. Total abundance of all fish species pooled fluctuated seasonally, peaking in summer. Total abundance at sites within locations differed, but sites at different locations overlapped in abundance. The dynamics of these communities were apparently unrelated to family membership among species, intraspecific abundances or diet. Rank abundances of species present at both locations did not differ, and only a single negative correlation of abundances between species was detected. Changes in abundance, however, were density dependent. Maximum abundance of fishes observed in the first summer explained between 42 and $93 \%$ of the variation in subsequent per capita declines in abundance by the following winter and before recruitment had commenced in the second year. These density-dependent effects were observed across families and across widely separated locations. These results suggest that the dynamics of these communities were not structured by strong pairwise interspecific interactions, but, instead, may have been structured by some density-dependent process(es) that affected a broad cross section of species and that operated irrespective of locality.
\end{abstract}

KEY WORDS: Community dynamics · Coral-reef fishes Density dependence - Latitudinal comparisons

\section{INTRODUCTION}

The structure and dynamics of natural communities can be determined by processes operating in both evolutionary and ecological time and on both local and larger spatial scales. For instance, evolutionary processes will determine the structure of the species pool from which a local community can be assembled. In turn, species pools from which local communities are assembled can vary. Where species pools vary, the dynamics of local communities drawn from these different pools may be affected by the identities and abundances of species present in the pool (Caley 1991). Furthermore, local ecological interactions can determine whether species persist in the pool (Levin 1974. Caswell 1978, Pulliam 1988). Thus, processes

•E-mail: julian.caley@jcu.edu.au operating on any of these 4 temporal and spatial scales have the potential to affect the structure and dynamics of ecological communities and to interact in complex ways.

In the last few decades the importance of evolutionary and large-scale spatial effects on local community structure and dynamics has been largely eclipsed by ecologists focusing on local processes operating in ecological time (Ricklefs 1987). There has been, however, a recent resurgence of interest in the roles played by processes operating on geographical scales and over historical time in organizing natural communities (contributions in Ricklefs \& Schluter 1993). Such studies have reinforced the idea that the structure of local communities may not be independent of the regions in which they are imbedded (Cornell \& Lawton 1992, Cornell 1993, Schluter \& Ricklefs 1993, Westoby 1993). While similarities and differences in the structure of local communities among regions are now being con- 
sidered, there has been a general lack of studies that have examined the dynamics of local communities in widely separated locations using identical protocols and with sufficient replication at small spatial scales to allow robust large-scale comparisons (Underwood \& Petraitis 1993, but see Dethier \& Duggins 1988).

The spectacular diversity of fishes inhabiting tropical reefs has attracted considerable research interest (Sale 1991). This research has paralleled that examining other faunal groups in that it has concentrated on local ecological interactions and biogeographical distributions (Allen 1975, 1991, Sale 1980, Springer 1982, Russell 1983, Williams \& Hatcher 1983, Russ 1984, Myers 1989, Choat \& Bellwood 1991, Thresher 1991). As with the research that has examined other faunal groups, little attention has been paid to the potential importance of differences among communities at larger spatial scales and how they might affect local patterns of coexistence of fishes on tropical reefs (but see Talbot \& Gilbert 1981, Caley 1991).

How and why might local dynamics of tropical fish communities differ among distant locations, and how might such differences be related to differences in community structure between locations? There are many possibilities. The timing (Pitcher 1988) and magnitude of demographic events, such as recruitment (Sweatman 1985), may vary between locations, and the magnitude and timing of such events may be related to differences in the species pools from which local assemblages are drawn. For instance, if local communities in one location are dominated by species that recruit either synchronously, or in large numbers, the demography of these species following recruitment may be considerably different from those in communities dominated by species that recruit either asynchronously or in smaller numbers. Likewise, differences in the abundance of species reliant on the same resources or that share a predator/prey relationship may influence the outcome of interspecific interactions. Therefore, just as local community structure may be dependent on regional patterns of diversity, so too might local community dynamics vary geographically.

I designed this study to examine patterns of community dynamics of reef fishes occurring locally and at a large spatial scale. To accomplish this comparison, I censused communities of reef fishes at 2 widely separated locations, Lizard Island and One Tree Island, over a 16 mo period. At these locations the composition of the species pools (Russell 1983) and within-species patterns of abundances can differ (Sweatman 1985, Caley 1991, this study). Therefore, fish communities at these locations provided the opportunity to examine the effects of differences occurring at a large spatial scale (i.e. between locations) on local patterns of coexistence. Using census data from these communities, I addressed the following questions. (1) Did patterns of abundance and the dynamics of local communities differ between locations widely separated in space and were any such differences consistent among taxa or trophic groups? (2) Were abundances within species related to the abundance of other species? (3) Were changes in reef fish abundance related to their density?

\section{METHODS}

Sampling design. I conducted this study at 2 locations on Australia's Great Barrier Reef (GBR) that were separated by $>1000 \mathrm{~km}$. The northern location was at Lizard Island $\left(14^{\circ} 38^{\prime} \mathrm{S}, 145^{\circ} 28^{\prime} \mathrm{E}\right)$ in the Cairns Section of the GBR, while the southern location was at One Tree Island $\left(23^{\circ} 30^{\prime} \mathrm{S}, 152^{\circ} 06^{\prime} \mathrm{E}\right)$ in the CapricornBunker Group of Islands. This study sampled over 16 mo from January 1989 to April 1990. Fish communities inhabiting patches of coral rubble at the bases of large patch reefs were censused 5 times at each location. Rubble patches were located in 3 to $7 \mathrm{~m}$ of water. Censuses were conducted during early and late summer of 2 consecutive years (1989 and 1990) and the intervening winter (referred to below as census periods). The timing of census periods was selected to maximize the annual range in fish abundance that might be expected in this habitat.

Although this sampling program ran concurrently at both locations, it was not possible to census the communities at these locations simultaneously. Therefore, the order in which locations were visited was randomized for each census period. Within each location, 2 sites were randomly selected, as were 6 rubble patches within each site. Sites within locations were separated by 0.5 to $1.0 \mathrm{~km}$. Patches within sites were censused only once, and new patches were selected at each census period. Each rubble patch within a census period was separated from other censused patches by at least $15 \mathrm{~m}$.

Sampling methods. Rubble patches were selected that abutted a vertical or nearly vertical wall of a patch reef. A $2 \times 2 \mathrm{~m}$ patch of rubble was delineated using 4 buoys that were weighted to the substratum and attached by $2 \mathrm{~m}$ of rope. After marking a patch in this manner I left the area for a minimum of $5 \mathrm{~min}$. On returning, I censused the fish community within this $8 \mathrm{~m}^{3}$ volume of habitat. Fish were counted for 5 min from as far away as visibility would allow All fishes within the patch were counted and identified following the taxonomic nomenclature of Randall et al. (1990). Fish that obviously moved in and out of the census area repeatedly were counted once. Following the 5 min census period, I approached the rubble patch and 
closely examined the substratum for small and/or cryptic fishes not previously counted. I continued examining the substratum in this manner until no additional species had been detected for at least $2 \mathrm{~min}$.

Analyses. Analyses included only those species that appeared to be resident within the patches of censused habitat during a particular census. For instance, on a number of occasions large schools of fusiliers (Caesio spp.) and parrotfishes (Scarus spp.) moved quickly through the census areas. There were no apparent interactions between these roving fishes and the rest of the fish community, nor did the scarids ever stop to feed in these areas. Therefore, these fishes were excluded from all analyses. Juvenile scarids, on the other hand, spent considerable time feeding within these areas and are included in the analyses below.

I examined the spatial and temporal dynamics of the fish communities inhabiting these rubble patches using 3-factor ANOVA. Census period and location were analyzed as fixed effects while sites within locations were analyzed as a random effect. Homogeneity of variances was examined using Cochran's test and heterogeneity was removed by $\log _{10}(x+1)$ or $(x+0.5)^{05}$ transformation. Non-significant interaction terms were pooled where $\mathrm{p}>0.25$ (Winer 1971, Mead 1988). Following significant ANOVAs, means were compared using Ryan's $Q$ test (Day and Quinn 1989). Because this design was a mixed effects ANOVA with sites nested within locations, tests of site effects were more powerful than tests of location effects. Therefore, location effects in this experiment may have been underestimated compared with site effects.

Two species of damselfishes (Pomacentridae) were occasionally in such great abundance that their numbers would have obscured any trends in the abundance of other species (Table 1). One of these species, Neopomacentrus azysron, only occurred at Lizard Island and the other species, Acanthochromis polyacanthus, only occurred in large numbers at One Tree Island. These species were excluded from the following analyses.

Because there was no reason to assume that the dynamics of all species within these communities would be similar in either time or space, separate analyses were conducted using sets of species. These sets included all species pooled, all species of blennies and gobies (Blenniidae and Gobiidae; these 2 families were lumped because of their low numbers and mostly similar benthic and cryptic lifestyles) pooled, all species of wrasses (Labridae) pooled, and all species of damselfishes (Pomacentridae) pooled. In addition, each species that occurred at both locations, and was sufficiently abundant to calculate the ANOVA, was analyzed separately. Results of these analyses were used to examine spatial and temporal patterns of abundance. These results were also used to examine associations among within-species abundance patterns and diet. Diet categories of species were determined from published sources (Hiatt \& Strasburg 1960, Myers 1989, Allen 1991).

The relative abundances of species within these communities were assessed in 2 ways. First, I examined the relative abundance of species and families to see if communities at these locations were dominated numerically by different families or species. I used Wilcoxon's signed-ranks test to compare the total number of individuals of each species censused at each location throughout the study. Next I examined intraand interfamilial differences in rank abundances between locations. Here, rank abundances of all species of blennies and gobies, wrasses, and damselfishes were examined separately for each family. I included in all ranks tests only species that were present at both locations. Second, I examined pairwise associations of abundances between species to see if interspecific abundances were related. Here, pairwise Pearson product-moment correlations were calculated using the total abundance of each species present at each location pooled across censuses. Bonferroni probabilities were calculated for these correlations to maintain an experiment-wise error rate of $5 \%$.

Finally, I examined whether fluctuations in abundance were related to the density of fishes within these communities. Because rubble patches were chosen at random for each census, I could not monitor changes in abundance in individual habitat patches. I could, however, monitor changes in abundance at sites within locations. For each census of each site I averaged abundances of all replicates. I then tested for densitydependent declines in abundance from the mean maximum abundance per site observed in the first year to the mean minimum abundance per site observed in the winter of the first year and before recruitment in the second year began. Declines in abundance were expressed as proportions and regressed on maximum abundance. Because abundances of individual species were often small during this study, my ability to detect density-dependent effects would have been reduced by random variation in intraspecific analyses. Therefore, I pooled species by family to increase my ability to detect such effects, if present, at the family level. Density-dependent declines in abundance were explored separately for all species pooled, all species of blennies and gobies pooled, all species of wrasses pooled, and all species of damselfishes pooled.

Each regression of proportional decline on maximum abundance was calculated using 4 estimates (i.e. 2 sites $\times 2$ locations) of each $x$ (maximum abundance) and $y$ (proportional decline) variable. Because of the 
Table 1. Total and rank abundances of fish species observed on rubble patches at both Lizard Island (LZ) and One Tree Island (OT). Species abundances pooled from 5 censuses over 16 mo

\begin{tabular}{|c|c|c|c|c|c|c|}
\hline $\begin{array}{l}\text { Family } \\
\quad \text { Species }\end{array}$ & \multicolumn{3}{|c|}{ Abundance } & - & $\begin{array}{c}\text { Rank } \\
\text { OT }\end{array}$ & Total \\
\hline \multicolumn{7}{|l|}{ Acanthociinidar } \\
\hline Belonepterygion fasciolatum & 1 & & 1 & 33 & & 45 \\
\hline \multicolumn{7}{|l|}{ Acanthuridae } \\
\hline Acanthurus spp. (juvenile) & 1 & & 1 & 33 & & 45 \\
\hline Ctenochaetus binotatus & 3 & & 3 & 31 & & 43 \\
\hline Ctenochaetus striatus & 3 & 3 & 6 & 31 & 27 & 40 \\
\hline \multicolumn{7}{|l|}{ Apogonidae } \\
\hline Apogon sp. (juvenile) & 3 & & 3 & 31 & & 43 \\
\hline Cheilodipterus quinquelineatus & 1 & 12 & 13 & 33 & 20 & 33 \\
\hline \multicolumn{7}{|l|}{ Balistidae } \\
\hline Sufflamen chrysopterus & 3 & & 3 & 31 & & 43 \\
\hline \multicolumn{7}{|l|}{ Blenniidae } \\
\hline Aspidontus dussumieri & & 2 & 2 & & 28 & 44 \\
\hline Atrosalarias fuscus & 1 & 1 & 2 & 33 & 29 & 44 \\
\hline Ecsenius bicolor & 2 & & 2 & 32 & & 44 \\
\hline Ecsenius mandibularis & & 2 & 2 & & 28 & 44 \\
\hline Ecsenius stictus & 3 & & 3 & 31 & & 43 \\
\hline Meiacanthus grammistes & 6 & & 6 & 28 & & 40 \\
\hline Meiacanthus lineatus & & 1 & 1 & & 29 & 45 \\
\hline Petroscirtes xestus & 1 & & 1 & 33 & & 45 \\
\hline Plagiotremus rhinorhynchos & 2 & & 2 & 32 & & 44 \\
\hline Plagiotremus tapeinosoma & 3 & 3 & 6 & 31 & 27 & 40 \\
\hline Salarias fasciatus & & 3 & 3 & & 27 & 43 \\
\hline Salarias sp. & 7 & & 7 & 27 & & 39 \\
\hline Stanulus sp. & 5 & & 5 & 29 & & 41 \\
\hline \multicolumn{7}{|l|}{ Chaetodontidae } \\
\hline Chaetodon auriga & 6 & 3 & 9 & 28 & 27 & 37 \\
\hline Chaetodon flavirostris & & 1 & 1 & & 29 & 45 \\
\hline Chaetodon kleinii & 1 & 1 & 2 & 33 & 29 & 44 \\
\hline Chaetodon lunula & & 1 & 1 & & 29 & 45 \\
\hline Chaetodon plebeius & 3 & 1 & 4 & 31 & 29 & 42 \\
\hline Chaetodon rainfordi & 2 & 5 & 7 & 32 & 25 & 39 \\
\hline Chelmon rostratus & & 6 & 6 & & 24 & 40 \\
\hline Gobiidae & & & & & & \\
\hline Amblygobius phalaena & 36 & 46 & 82 & 14 & 11 & 13 \\
\hline Amblygobius rainfordi & & 2 & 2 & & 28 & 44 \\
\hline Asterropteryx semipunctatus & 24 & 55 & 79 & 19 & 9 & 15 \\
\hline Cryptocentrus cinctus & 1 & & 1 & 33 & & 45 \\
\hline Cryptocentrus strigilliceps & 1 & & 1 & 33 & & 45 \\
\hline Fusigobius neophytus & & 1 & 1 & & 29 & 45 \\
\hline Istigobius ngilius & 10 & 2 & 12 & 25 & 28 & 34 \\
\hline Valenciennea longipinnis & 1 & 6 & 7 & 33 & 24 & 39 \\
\hline Valenciennea strigata & & 1 & 1 & & 29 & 45 \\
\hline Haemulidae & & & & & & \\
\hline Diagramma pictum & & 3 & 3 & & 27 & 43 \\
\hline Labridae & & & & & & \\
\hline Cheilinus chlorourus & 6 & 11 & 17 & 28 & 21 & 30 \\
\hline Cheilinus digrammus & & 2 & 2 & & 28 & 44 \\
\hline Cheilnnus fascratus & & 3 & 3 & & 27 & 43 \\
\hline Choerodon fasciatus & & 2 & 2 & & 28 & 44 \\
\hline Cirrhilabrus punctatus & & 109 & 109 & & 4 & 9 \\
\hline Coris dorsomacula & & 12 & 12 & & 20 & 34 \\
\hline Coris schroederi & 149 & 86 & 235 & 3 & 7 & 4 \\
\hline Epibulus insidiator & & 1 & 1 & & 29 & 45 \\
\hline Halichoeres chloropterus & 20 & & 20 & 21 & & 28 \\
\hline Halichoeres melanurus & 81 & 7 & 88 & 6 & 23 & 12 \\
\hline Halichoeres nebulosus & & 3 & 3 & & 27 & 43 \\
\hline Halichoeres prosopeion & & 1 & 1 & & 29 & 45 \\
\hline Halichoeres trimaculatus & 4 & 14 & 18 & 30 & 19 & 29 \\
\hline Hemigymnus fasciatus & $i$ & 2 & 3 & 33 & 28 & 43 \\
\hline Hemigymnus melapterus & 1 & 3 & 4 & 33 & 27 & 42 \\
\hline Labrichthys unilineatus & & 4 & 4 & & 26 & 42 \\
\hline Labroides dimidiatus & 14 & 21 & 35 & 23 & 17 & 22 \\
\hline Leptojulis cyanopleura & & 1 & 1 & & 29 & 45 \\
\hline Macropharyngodon meleagns & & 2 & 2 & & 28 & 44 \\
\hline Stetholulis bandanensis & & 1 & 1 & & 29 & 45 \\
\hline Stethojulis strigiventer & 58 & 23 & 81 & 8 & 15 & 14 \\
\hline Thalassoma hardwicke & & 1 & 1 & & 29 & 45 \\
\hline Thalassoma lunare & 40 & 119 & 159 & 12 & 3 & 7 \\
\hline
\end{tabular}


Table 1 (continued)

\begin{tabular}{|c|c|c|c|c|c|c|}
\hline $\begin{array}{l}\text { Family } \\
\quad \text { Species }\end{array}$ & \multicolumn{3}{|c|}{ Abundance } & $\mathrm{LZ}$ & $\begin{array}{c}\text { Rank } \\
\text { OT }\end{array}$ & Total \\
\hline \multicolumn{7}{|l|}{ Lutjanidae } \\
\hline Lutjanus carponotatus & 14 & 8 & 22 & 23 & 22 & 27 \\
\hline Lutjanus fulviflamma & 11 & & 11 & 24 & & 35 \\
\hline Lutjanus gibbus & 3 & & 3 & 31 & & 43 \\
\hline \multicolumn{7}{|l|}{ Microdesmidae } \\
\hline Ptereleotris microlepis & 2 & 1 & 3 & 32 & 29 & 43 \\
\hline \multicolumn{7}{|l|}{ Mullidae } \\
\hline Parupeneus barberinus & 10 & & 10 & 25 & & 36 \\
\hline Parupeneus ciliatus & 8 & & 8 & 26 & & 38 \\
\hline Parupeneus cyclostomus & 1 & & 1 & 33 & & 45 \\
\hline Parupeneus pleurostigma & 1 & & 1 & 33 & & 45 \\
\hline \multicolumn{7}{|l|}{ Nemipteridae } \\
\hline Scolopsis bilineatus & 41 & 29 & 70 & 11 & 12 & 17 \\
\hline Scolopsis monogramma & 15 & 2 & 17 & 22 & 28 & 30 \\
\hline \multicolumn{7}{|l|}{ Pinguipedidae } \\
\hline Parapercis cylindrica & 25 & 54 & 79 & 18 & 10 & 15 \\
\hline Parapercis hexophtalma & 1 & 14 & 15 & 33 & 19 & 31 \\
\hline \multicolumn{7}{|l|}{ Pomacanthidae } \\
\hline Centropyge tibicen & & 1 & 1 & & 29 & 45 \\
\hline \multicolumn{7}{|l|}{ Pomacentridae } \\
\hline Abudefduf sexfasciatus & 6 & 22 & 28 & 28 & 16 & 25 \\
\hline Acanthochromis polyacanthus & 38 & 165 & 203 & 13 & 2 & 5 \\
\hline Amblyglyphidodon curacao & 33 & 8 & 41 & 15 & 22 & 21 \\
\hline Amphiprion akindynos & 1 & & 1 & 33 & & 45 \\
\hline Chromis vindis & 15 & & 15 & 22 & & 31 \\
\hline Chrysiptera flavipinnus & 2 & & 2 & 32 & & 44 \\
\hline Chrysiptera rex & 1 & & 1 & 33 & & 45 \\
\hline Chrysiptera rollandi & 81 & 96 & 177 & 6 & 5 & 6 \\
\hline Dascyllus aruanus & 2 & & 2 & 32 & & 44 \\
\hline Dischistodus melanotus & 2 & 7 & 9 & 32 & 23 & 37 \\
\hline Dischistodus perspicillatus & 46 & 1 & 47 & 10 & 29 & 19 \\
\hline Dischistodus prosopotaenia & 26 & 3 & 29 & 17 & 27 & 24 \\
\hline Neoglyphidodon melas & 1 & 22 & 23 & 33 & 16 & 26 \\
\hline Neopomacentrus azysron & 1196 & & 1196 & 1 & & 1 \\
\hline Pomacentrus adelus & 60 & & 60 & 7 & & 18 \\
\hline Pomacentrus ambounensis & 320 & 89 & 409 & 2 & 6 & 2 \\
\hline Pomacentrus bankanensis & 3 & 1 & 4 & 31 & 29 & 42 \\
\hline Pomacentrus brachialis & 4 & & 4 & 30 & & 42 \\
\hline Pomacentrus chrysurus & 87 & 12 & 99 & 5 & 20 & 11 \\
\hline Pomacentrus grammorhynchus & 1 & & 1 & 33 & & 45 \\
\hline Pomacentrus lepidogenys & 23 & & 23 & 20 & & 26 \\
\hline Pomacentrus moluccensis & 97 & 15 & 112 & 4 & 18 & 8 \\
\hline Pomacentrus nagasakiensis & 32 & 11 & 43 & 16 & 21 & 20 \\
\hline Pomacentrus pavo & 10 & 1 & 11 & 25 & 29 & 35 \\
\hline Pomacentrus wardi & 46 & 60 & 106 & 10 & 8 & 10 \\
\hline \multicolumn{7}{|l|}{ Pseudochromidae } \\
\hline Ogilbyina novaehollandiae & & 2 & 2 & & 28 & 44 \\
\hline Pseudochromis fuscus & 50 & 25 & 75 & 9 & 14 & 16 \\
\hline \multicolumn{7}{|l|}{ Scaridae } \\
\hline Scarus sordidus & 3 & 27 & 30 & 31 & 13 & 23 \\
\hline Scarus spp. (juvenile) & 38 & 267 & 305 & 13 & 1 & 3 \\
\hline Serranidae & & & & & & \\
\hline Cephalopholis boenak & 2 & & 2 & 32 & & 44 \\
\hline Diploprion bifascialum & 1 & & 1 & 33 & & 45 \\
\hline PJectropomus leopardus & & 2 & 2 & & 28 & 44 \\
\hline Siganidàe & & & & & & \\
\hline Siganus doliatus & 2 & 4 & 6 & 32 & 26 & 40 \\
\hline Siganus punctatus & 2 & & 2 & 32 & & 44 \\
\hline Siganus sp. (juvenile) & 14 & & 14 & 23 & & 32 \\
\hline Synodontidae & & & & & & \\
\hline Synodus dermatogenys & 2 & & 2 & 32 & & 44 \\
\hline Tetraodontidae & & & & & & \\
\hline Arothron hispidus & 1 & & 1 & 33 & & 45 \\
\hline Canthigaster bennetti & 1 & & 1 & 33 & & 45 \\
\hline Canthigaster valentini & & 2 & 2 & & 28 & 44 \\
\hline Trichonotidae & & & & & & \\
\hline Trichonotus sp. & 8 & & 8 & 26 & & 38 \\
\hline
\end{tabular}


small number of points used in these regressions, violations of assumptions of parametric statistical techniques were likely. Therefore, p-values for these relationships were calculated using exact randomization tests (Sokal \& Rohlf 1981). p was calculated as the probability of exceeding the observed $\mathrm{r}^{2}$ when the sign of the slope of the randomized data was the same as that of the observed data. These procedures, therefore, constitute a 1-tailed test.

\section{RESULTS}

\section{Temporal patterns of abundance}

For all fish species pooled, abundances varied among censuses (Table 2A), but post-hoc comparisons failed to detect significant differences among means. Abundance of fishes, however, tended to peak during summer and decline towards winter. This trend was repeated in all comparisons in which seasons differed. This was true for both families and species and whether or not season interacted with location (Table 2). Species within families, however, showed no consistency in seasonal patterns. For instance, neither all labrids (Table 2E) nor all pomacentrids (Table 2J) fluctuated seasonally. Abundance of one species of labrid, however, did fluctuate seasonally (Coris schroederi, Table $2 \mathrm{~F}$ ) while fluctuations in abundance of one species of pomacentrid was strongly suggestive of a similar seasonal trend (Pomacentrus wardi, Table 2N). Similarly, the likelihood that intraspecific abundance would fluctuate seasonally was not related to the total abundance of a particular species. For instance, $C$. schroederi was the most abundant wrasse (Table 1) and fluctuated seasonally at both locations (Table $2 \mathrm{~F}$ ), whereas the total abundance of $P$. wardi, the pomacentrid species that fluctuated seasonally (Table $2 \mathrm{~N}$ ), was intermediate in abundance to other pomacentrids (Table 1) whose abundance did not vary statistically. Furthermore, both species of blennies and gobies, Asterropteryx semipunctatus and Amblygobius phalaena, were nearly equally abundant (Table 1). Yet, one fluctuated in abundance seasonally at both locations while the other did not (Table 2C, D).

\section{Spatial patterns of abundance}

During this study, fish abundances varied both between locations and among sites. For all species pooled, total abundance varied among sites, but the range of abundances at sites within locations overlapped between locations (Table 2A). Therefore, there were no clear differences in total abundance of fishes at these 2 very distant locations. In contrast, patterns of spatial variation in abundance differed among families. Blennies and gobies were similarly abundant at all sites and locations (Table 2B), whereas the abundance of both labrids and pomacentrids varied among sites (Table 2E, J). The abundance of labrids within sites overlapped between locations, indicating that sites within locations were at least as different as locations themselves. Pomacentrids, on the other hand, were clearly more abundant on both sites at Lizard Island than on both sites at One Tree Island.

Spatial variation in abundance among sites and between locations was detected for some species. As with temporal variation, spatial variation was unrelated to intraspecific abundance within families (Table 1). For instance, the abundance of Asterropteryx semipunctatus varied among sites (Table $2 \mathrm{C}$ ) while the abundance of Amblyogobius phalaena did not (Table 2D). Two of the 4 wrasse species, Thalassoma lunare (Table $2 \mathrm{H}$ ) and Stethojulis strigiventer, (Table 2I) varied between locations or among sites, respectively. In contrast, there was no evidence that Coris schroederi (Table $2 \mathrm{~F}$ ) or Labroides dimidiatus (Table 2G) varied at either spatial scale. The abundance of all species of pomacentrid (Table $2 \mathrm{~K}-\mathrm{N}$ ) varied among sites, but sites were not clearly different between locations. Pseudochromis fuscus was more abundant at Lizard Island than at One Tree Island (Table 20).

\section{Abundance and diets}

Because relatively few species were sufficiently abundant for ANOVA, only a few comparisons of abundance in relation to diet could be made. The available comparisons, however, suggest that patterns of abundance of the species examined here were not strongly related to diet. For instance, of 3 species of wrasse that feed primarily on small invertebrates, 2 species (i.e. Thalassoma lunare, Table $2 \mathrm{H}_{i}$ Stethojulis strigiventer, Table 2I) varied significantly in abundance between locations and among sites, respectively, while one species varied significantly in abundance only among census periods (i.e. Coris schroederi, Table 2F). Conversely, 2 species of omnivorous damselfishes both varied significantly in abundance among sites (Chrysiptera rollandi, Table $2 \mathrm{~K}$. Pomacentrus amboinensis Table $2 \mathrm{M}$ ). However, $P$. amboinensis was more abundant at one site at Lizard Island, whereas the abundance of $C$. rollandi did not differ clearly among sites. Therefore, this limited set of comparisons reveals no consistent similarities or differences in abundance within diet groups 


\section{Interspecific associations in abundance}

There was no evidence that rank abundances of all fish species were consistent between Lizard Island and One Tree Island (Table 1; Wilcoxon signed-ranks tests; all species $p>0.28$ ), nor were species ranks within families (Wilcoxon signed-ranks tests; Blenniidae and Gobiidae, $p>0.18$, Labridae, $p>0.75$, Pomacentridae, $p>0.17$ ). Comparisons of abundances between species revealed a single, statistically-significant, negative correlation (Pomacentrus wardiversus $P$, amboinensis, $\mathrm{n}=60, \mathrm{r}=-0.45$, Bonferroni $\mathrm{p}<0.02)$. P. wardi was more abundant at one site at Lizard Island and $P$. amboinensis was more abundant at the other. Therefore, this negative correlation was likely the result of intrinsic differences between sites in the abundance of these 2 species, rather than the result of one species excluding the other at both sites. Furthermore, a similar relationship between these 2 species was not observed at the One Tree Island sites. Therefore, no strong interspecific interactions were evident in this study.

\section{Density-dependent declines in abundance}

Density-dependent declines in abundance were detected in the fish communities at Lizard Island and One Tree Island. Between 42 and $93 \%$ of the variation in proportional declines from summer maximum to winter minimum abundances of fishes were explained by previously reached maximum densities. The strongest relationships were detected for all species pooled (Fig. 1A) and pomacentrids pooled (Fig. 1D). Densitydependent declines were evident but less strong for blennies and gobies pooled (Fig. 1B) and labrids pooled (Fig. 1C). Although these latter relationships explained 42 and $64 \%$ of the variation in proportional decline, respectively, they were not statistically significant $(p>0.05)$. Both of these taxonomic groupings were the least abundant groups in the communities for which declines in abundance were examined.

\section{DISCUSSION}

The relative importance of pre- versus postrecruitment and density-dependent versus density-independent processes in determining patterns of distribution and abundance of reef fishes continues to be debated
(Doherty 1991, Hixon 1991, Jones 1991). Meanwhile, evidence of density-dependent, post-recruitment effects on abundance in coral-reef fish populations continues to accumulate. For instance, the survival of newly recruited fishes can be affected by the density of conspecifics (Hunte \& Côté 1989, Forrester 1990, Jones 1990, Stimson 1990, Tupper \& Hunte 1994, Booth 1995). Previously, however, such evidence has been limited to the demonstration of density-dependent effects on small spatial scales affecting single species, often in artificial experimental situations. In contrast, this study documents density-dependent changes in abundance in natural communities of reef fishes from sites 0.5 to $1 \mathrm{~km}$ apart and locations greater than $1000 \mathrm{~km}$ apart. Furthermore, it indicates that densitydependent processes may affect the abundance of fishes in a variety of fish taxa. It should be noted, however, that these results are based on few data points.

Currently, there is much debate regarding the appropriate interpretations of statistically significant density dependence (Hanski et al. 1993. Holyoak \& Lawton 1993, Wolda \& Dennis 1993, Dennis \& Taper 1994, Wolda et al. 1994). Density dependence can be detected either in the presence of a demographic

- Lizard Island

- One Tree Island

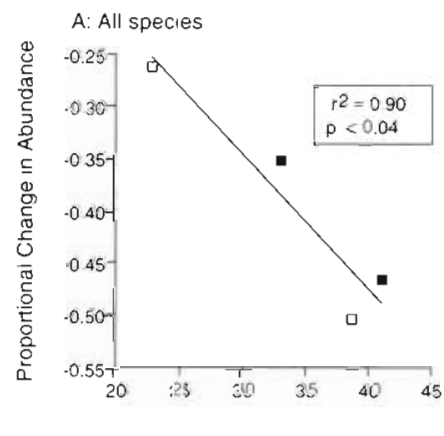

B: Blennildae and Gobildae
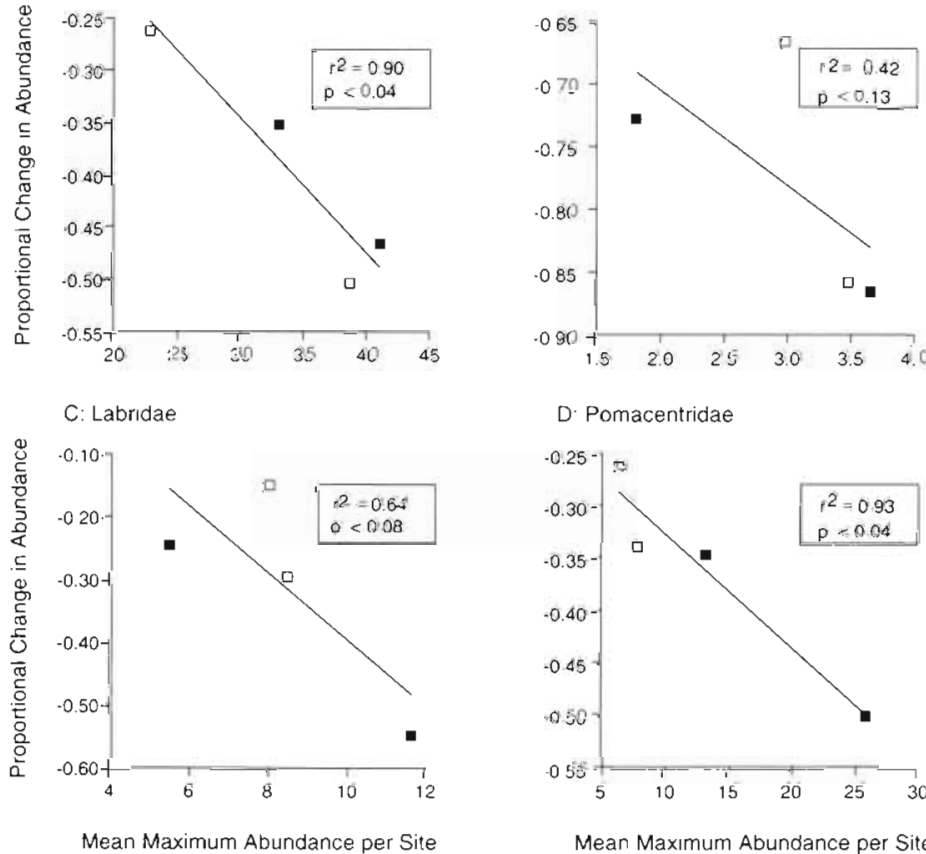

D. Pomacentridae

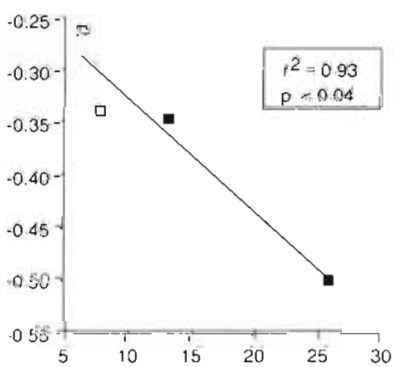

Mean Maximum Abundance per Site

Fig. 1 Proportional changes in abundance of fishes from the summer maximum observed in the first year of the study to the following winter minimum regressed against maximum abundance at each site. Plotted values are for sites within locations. Values for sites calculated as the mean value of replicates within sites. p-values determined by exact randomization methods (see text for details) 
Table 2. Summaries of ANOVAs and post-hoc comparisons of means for total abundance of censused individuals from selected taxa and combinations of taxa. C: census period; L: location; $\mathrm{S}(\mathrm{L})$ : sites within locations. Pld: MS(denominator) from pooled sources of variation indicated by a To simplify table, $F$ - and p-values have been omitted for factors and interactions where $p>0.25$. ES1: early summer year 1 ; ES2: early summer year 2; LS1. late summer year $1 ;$ LS2: late summer year $2 ;$ W: winter, LZ1, LZ2: Lizard Island Sites 1 and 2; OT1, OT2: One Tree Island Sites 1 and 2. Means sharing common underline did not differ at $p<0.05$ (Ryan's $Q_{i}$ Day \& Quinn 1989)

\begin{tabular}{|c|c|c|c|c|c|c|c|c|c|c|c|}
\hline \multicolumn{6}{|c|}{ Analyses of variance } & \multicolumn{6}{|c|}{ Comparisons of means } \\
\hline Source & df & MS & $F$ & $\mathrm{p}$ & $F$ vs: & & & & & & \\
\hline \multicolumn{12}{|c|}{ (A) All species } \\
\hline $\mathrm{C}$ & 4 & 569.3 & 8.0 & $<<0.001$ & $\mathrm{Pld}^{\mathrm{a}}$ & Census & ES1 & LS2 & ES2 & LS1 & W \\
\hline $\mathrm{L}$ & 1 & 448.5 & & & & Mean & 34 & 28.5 & 24 & 23.5 & 22.1 \\
\hline$S(L)$ & 2 & 341.2 & 4.8 & 0.01 & Pld ${ }^{\mathrm{d}}$ & & & & & & \\
\hline $\mathrm{C} \times \mathrm{L}$ & 4 & 164.3 & 2.3 & $<0.061$ & $\mathrm{Pld}^{\mathrm{a}}$ & Site & LZ1 & OT1 & LZ2 & OT2 & \\
\hline $\mathrm{C} \times \mathrm{S}(\mathrm{L})$ & 8 & $84.8^{\mathrm{d}}$ & & & & Mean & 30.7 & 27 & 26 & 22.1 & \\
\hline Residual & 100 & $69.8^{d}$ & & & & & & & & & \\
\hline \multicolumn{12}{|c|}{ (B) Blenniidae and Gobiidae } \\
\hline C & 4 & 17.7 & 4.5 & 0.002 & $\mathrm{Pld}^{\mathrm{a}}$ & Census LZ & LS2 & ES1 & ES2 & W & LS1 \\
\hline $\mathrm{L}$ & 1 & 2.7 & & & & Mean & 3.3 & 2.8 & 1.5 & 1 & 0.5 \\
\hline S(L) & 2 & 1.0 & & & & & & & & & \\
\hline $\mathrm{C} \times \mathrm{L}$ & 4 & 11.6 & 2.9 & 0.024 & PId $^{\mathrm{d}}$ & Census OT & LS1 & ES1 & LS2 & W & ES2 \\
\hline$C \times S(L)$ & 8 & $2.4^{\mathrm{d}}$ & & & & Mean & 3.2 & 2.8 & 2.6 & 1.3 & 0.8 \\
\hline Residual & 100 & $4.1^{\circ}$ & & & & & & & & & \\
\hline \multicolumn{12}{|c|}{ (C) Asterropteryx semipunctatus } \\
\hline C & 4 & 2.1 & 1.9 & 0.114 & Pld ${ }^{a}$ & Site & OT1 & LZ2 & OT2 & LZ1 & \\
\hline $\mathrm{L}$ & 1 & 7.5 & & & & Mean & 1.2 & 0,6 & 0.6 & 0.2 & \\
\hline$S(L)$ & 2 & 3.9 & 3.5 & 0.034 & $\mathrm{Pld}^{\mathrm{a}}$ & & & & & & \\
\hline $\mathrm{C} \times \mathrm{L}$ & 4 & 1.6 & 1.4 & 0.228 & Pld $^{a}$ & & & & & & \\
\hline $\mathrm{C} \times \mathrm{S}(\mathrm{L})$ & 8 & $0.7^{\mathrm{a}}$ & & & & & & & & & \\
\hline Residual & 100 & $1.2^{\mathrm{a}}$ & & & & & & & & & \\
\hline \multicolumn{12}{|c|}{ (D) Amblygobius phalaena [Iog(x+1) transiormed] } \\
\hline $\mathrm{C}$ & 4 & 0.2 & 4.9 & 0.001 & Pld & Census LZ & LS2 & ES2 & ES1 & LS1 & W \\
\hline $\mathrm{L}$ & 1 & 0.0 & & & & Mean & 1.3 & 0.8 & 0.5 & 0.3 & 0.1 \\
\hline $\mathrm{S}(\mathrm{L})$ & 2 & 0.1 & & & & & & & & & \\
\hline $\mathrm{C} \times \mathrm{L}$ & 4 & 0.1 & 2.4 & 0.054 & Pld & Census OT & LS1 & LS2 & ES1 & W & ES2 \\
\hline$C \times S(L)$ & 8 & $0.0^{\mathrm{a}}$ & & & & Mean & 1.3 & 1.3 & 0.8 & 0.3 & 0.3 \\
\hline Residual & 100 & $0.0^{\mathrm{d}}$ & & & & & & & & & \\
\hline \multicolumn{12}{|c|}{ (E) Labridae $\left[(x+0.5)^{0.5}\right.$ transformed] } \\
\hline C & 4 & 0.4 & & & & Site & LZ2 & OT1 & OT2 & LZ1 & \\
\hline $\mathrm{L}$ & $\uparrow$. & 0.4 & & & & Mean & 2.8 & 2.7 & 2.6 & 2.3 & \\
\hline$S(L)$ & 2 & 1.6 & 4.2 & 0.018 & $\mathrm{Pld}^{\mathrm{a}}$ & & & & & & \\
\hline $\mathrm{C} \times \mathrm{L}$ & 4 & $0.0^{d}$ & & & & & & & & & \\
\hline$C \times S(L)$ & 8 & 0.6 & & & & & & & & & \\
\hline Residual & 100 & $0.4^{a}$ & & & & & & & & & \\
\hline \multicolumn{12}{|c|}{ (F) Coris schroederi } \\
\hline C & 4 & 6.5 & 4.7 & 0.002 & $\mathrm{Pld}^{\mathrm{d}}$ & Census LZ & ES2 & LS1 & ES1 & LS2 & W \\
\hline L & 1. & 33.1 & 11 & 0.079 & $\mathrm{~S}(\mathrm{~L})$ & Mean & 3.1 & 2.8 & 2.5 & 2.5 & 1.5 \\
\hline $\mathrm{S}(\mathrm{L})$ & 2 & 2.9 & 2.1 & 0.122 & Pld ${ }^{d}$ & & & & & & \\
\hline$C \times L$ & 4 & 4.5 & 3.3 & 0.013 & $\mathrm{Pld}^{\mathrm{a}}$ & Census OT & LS2 & ES2 & ES1 & $w$ & LS1 \\
\hline $\mathrm{C} \times \mathrm{S}(\mathrm{L})$ & 8 & $1.3^{\mathrm{d}}$ & & & & Mean & 2.7 & 1.6 & 1.1 & 1 & 0.8 \\
\hline Residual & 100 & $1.4^{\mathrm{d}}$ & & & & & & & & & \\
\hline \multicolumn{12}{|c|}{ (G) Labroides dimidiatus $[\log (x+1)$ transformed] } \\
\hline $\mathrm{C}$ & 4 & 0.1 & & & & & & & & & \\
\hline L & 1 & 0.0 & & & & & & & & & \\
\hline$S(L)$ & 2 & 0.1 & & & & & & & & & \\
\hline$C \times L$ & 4 & $0.1^{\mathrm{d}}$ & & & & & & & & & \\
\hline $\mathrm{C} \times \mathrm{S}(\mathrm{L})$ & 8 & 0.3 & 2.6 & 0.013 & PId $d^{d}$ & & & & & & \\
\hline Residual & 100 & $2.1^{\mathrm{d}}$ & & & & & & & & & \\
\hline
\end{tabular}


Table 2 (continued)

\begin{tabular}{|c|c|c|c|c|c|c|c|c|c|c|c|}
\hline Source & $d f$ & MS & $F$ & $\mathrm{p}$ & Fvs: & & & & & & \\
\hline \multicolumn{12}{|c|}{ (H) Thalassoma lunare } \\
\hline $\mathrm{C}$ & 4 & 0.9 & & & & Location & OT & $\mathrm{LZ}$ & & & \\
\hline $\mathrm{L}$ & 1. & 52.0 & 20.5 & 0.046 & $\mathrm{~S}(\mathrm{~L})$ & Mean & 2.0 & 0.7 & & & \\
\hline$S(L)$ & 2 & 2.5 & 2.1 & 0.13 & Pld $^{\text {a }}$ & & & & & & \\
\hline$C \times L$ & 4 & 1.9 & 1.5 & 0.2 & Pld ${ }^{d}$ & & & & & & \\
\hline$C \times S(L)$ & 8 & $0.8^{\mathrm{d}}$ & & & & & & & & & \\
\hline Residual & 100 & $1.3^{\mathrm{a}}$ & & & & & & & & & \\
\hline \multicolumn{12}{|c|}{ (I) Stethojulis strigiventer $[\log (x+1)$ transformed] } \\
\hline $\mathrm{C}$ & 4 & 0.1 & 2.3 & 0.142 & $\mathrm{Pld}^{\mathrm{a}}$ & Site & LZ2 & LZ1 & OT1 & OT2 & \\
\hline $\mathrm{L}$ & 1 & 0.5 & 3.7 & 0.196 & $S(L)$ & Mean & 0.3 & 0.2 & 0.2 & 0.0 & \\
\hline $\mathrm{S}(\mathrm{L})$ & 2 & 0.1 & 3.7 & 0.028 & $\mathrm{Pld}^{a}$ & & & & & & \\
\hline $\mathrm{C} \times \mathrm{L}$ & 4 & $0.1^{\text {a }}$ & & & & & & & & & \\
\hline$C \times S(L)$ & 8 & 0.1 & 1.4 & 0.213 & $\mathrm{Pld}^{a}$ & & & & & & \\
\hline Residual & 100 & $0.0^{\mathrm{a}}$ & & & & & & & & & \\
\hline \multicolumn{12}{|c|}{ (J) Pomacentridae $[\log (x+1)$ transformed] } \\
\hline $\mathrm{C}$ & 4 & 0.1 & 1.8 & 0.137 & $\mathrm{Pld}^{\mathrm{a}}$ & Site & LZ1 & LZ2 & OT1 & OT2 & \\
\hline L & 1 & 4.1 & 12.0 & 0.073 & $\mathrm{~S}(\mathrm{~L})$ & Mean & 1.3 & 1.1 & 0.9 & 0.7 & \\
\hline$S(L)$ & 2 & 0.3 & 12.0 & $<<0.001$ & Pld $^{\text {a }}$ & & & & & & \\
\hline $\mathrm{C} \times \mathrm{L}$ & 4 & 0.1 & 2.2 & 0.07 & $\mathrm{Pld}^{\mathrm{a}}$ & & & & & & \\
\hline$C \times S(L)$ & 8 & $0.0^{a}$ & & & & & & & & & \\
\hline Residual & 100 & $0.0^{\mathrm{a}}$ & & & & & & & & & \\
\hline \multicolumn{12}{|c|}{ (K) Chrysiptera rollandi } \\
\hline C & 4 & 2.0 & & & & Site & OT1 & LZ1 & OT2 & $\mathrm{LZ2}$ & \\
\hline $\mathrm{L}$ & 1 & 1.9 & & & & Mean & 2.0 & 1.6 & 1.2 & 1.1 & \\
\hline$S(L)$ & 2 & 8.0 & 5.0 & 0.008 & Pld ${ }^{\mathrm{a}}$ & & & & & & \\
\hline$C \times L$ & 4 & 3.0 & 1.9 & 0.121 & $\mathrm{Pld}^{\star}$ & & & & & & \\
\hline $\mathrm{C} \times \mathrm{S}(\mathrm{L})$ & 8 & $0.5^{\mathrm{a}}$ & & & & & & & & & \\
\hline Residual & 100 & $1.7^{\mathrm{a}}$ & & & & & & & & & \\
\hline \multicolumn{12}{|c|}{ (L) Dischistodus perspicillatus [ $\log (x+1)$ transformed] } \\
\hline $\mathrm{C}$ & 4 & 0.0 & & & & Site & LZ2 & LZ1 & OT2 & OT1 & \\
\hline L. & 1 & 0.9 & 3.4 & 0.205 & $S(L)$ & Mean & 0.3 & 0.1 & 0.0 & 0.0 & \\
\hline $\mathrm{S}(\mathrm{L})$ & 2 & 0.3 & 10.0 & $<0.001$ & $\mathrm{Pld}^{\mathrm{a}}$ & & & - & & & \\
\hline $\mathrm{C} \times \mathrm{L}$ & 4 & $0.0^{\mathrm{a}}$ & & & & & & & & & \\
\hline $\mathrm{C} \times \mathrm{S}(\mathrm{L})$ & 8 & $0.0^{\mathrm{a}}$ & & & & & & & & & \\
\hline Residual & 100 & $0.0^{\mathrm{a}}$ & & & & & & & & & \\
\hline \multicolumn{12}{|c|}{ (M) Pomacentrus amboinensis [ $\log (x+1)$ transformed] } \\
\hline $\mathrm{C}$ & 4 & 0.0 & & & & Site & LZ1 & LZ2 & OT1 & OT2 & \\
\hline L & 1 & 3.0 & & & & Mean & 0.9 & 0.4 & 0.4 & 0.3 & \\
\hline$S(L)$ & 2 & 2.2 & 30.5 & $<<0.001$ & Pld $^{d}$ & & & & & & \\
\hline $\mathrm{C} \times \mathrm{L}$ & 4 & $0.0^{\mathrm{a}}$ & & & & & & & & & \\
\hline$C \times S(L)$ & 8 & $0.1^{\mathrm{a}}$ & & & & & & & & & \\
\hline Residual & 100 & $0.1^{\mathrm{a}}$ & & & & & & & & & \\
\hline \multicolumn{12}{|c|}{ (N) Pomacentrus wardi $[\log (x+1)$ transformed] } \\
\hline C & 4 & 0.1 & 2.4 & 0.051 & $\mathrm{Pld}^{\mathrm{a}}$ & Census & ES1 & ES2 & W & LS1 & LS2 \\
\hline $\mathrm{L}$ & 1 & 0.2 & & & & Mean & 0.3 & 0.3 & 0.2 & 0.3 & 0.1 \\
\hline$S(L)$ & 2 & 0.9 & 33.1 & $<<0.001$ & $\mathrm{Pld}^{\mathrm{a}}$ & & & & & & \\
\hline$C \times L$ & 4 & $0.0^{\mathrm{a}}$ & & & & Site & LZ2 & OT1 & OT2 & LZ1 & \\
\hline $\mathrm{C} \times \mathrm{S}(\mathrm{L})$ & 8 & $0.0^{\mathrm{a}}$ & & & & Mean & 0.4 & 0.3 & 0.2 & 0.0 & \\
\hline Residual & 100 & $0.0^{\mathrm{a}}$ & & & & & & & & & \\
\hline \multicolumn{12}{|c|}{ (O) Pseudochromis fuscus } \\
\hline $\mathrm{C}$ & 4 & 0.5 & & & & Location & $\mathrm{LZ}$ & OT & & & \\
\hline $\mathrm{L}$ & 1 & 5.2 & 125.5 & 0.008 & $\mathrm{~S}(\mathrm{~L})$ & Mean & 0.8 & 0.4 & & & \\
\hline$S(L)$ & 2 & 0.0 & & & & & & & & & \\
\hline $\mathrm{C} \times \mathrm{L}$ & 4 & 0.2 & & & & & & & & & \\
\hline $\mathrm{C} \times \mathrm{S}(\mathrm{L})$ & 8 & 0.2 & & & & & & & & & \\
\hline Residual & 100 & 0.5 & & & & & & & & & \\
\hline
\end{tabular}


process such as mortality, varying as a function of density, or in the presence of independent, identically distributed random variables (Wolda \& Dennis 1993). No consensus has yet been reached, however, regarding the rates of occurrence and relative importance of these 2 'types' of density dependence (cf. Hanski et al. 1993, Holyoak \& Lawton 1993, and Wolda et al. 1994). Furthermore, the cause(s) of density dependence cannot be discerned using observational data (Wolda \& Dennis 1993). Regardless of the source of densitydependent relationships, however, the detection of such relationships here suggests that future experimental studies of density-varying processes may be helpful in understanding the dynamics of this and similar marine systems

Despite the large distance separating the 2 locations studied here, spatial variation in abundance was often as great between sites within locations as between locations. For instance, the abundance of all species at sites at Lizard Island overlapped sites at One Tree Island. This pattern of overlap, however, was not observed for all families and species when analyzed separately. Labrids as a whole were similarly abundant at the 2 locations, but one species, Thalassoma lunare, was more abundant at One Tree Island. On the other hand, pomacentrids as a whole were clearly more abundant on rubble patches at Lizard Island than at One Tree Island. The abundances of each pomacentrid species, however, did not differ significantly between the 2 locations. Therefore, no clear distinctions can be made between the abundances observed at the 2 locations either within or among families.

No strong interspecific interactions were evident in this study. This result is consistent with previous studies of pairwise patterns of reef-fish abundance at One Tree Island on both natural and artificial reefs (Sale \& Dybdahl 1975, 1978, Talbot et al. 1978, Sale \& Steel 1989). Similar comparative studies have not been previously done at Lizard Island. Therefore, the results of this study provide new evidence that a lack of pairwise interspecific interactions in determining patterns of abundance may be more general than suggested by earlier studies at One Tree.

Elsewhere, I have argued that differences in predator abundance at these same locations can profoundly affect the structure and dynamics of fish communities on artificial reefs (Caley 1991). During this study, Pseudochromis fuscus was the only piscivorous fish sufficiently abundant for analysis. Their pattern of greater abundance at Lizard Island was consistent with my previous findings. The contribution of this predator to the community dynamics observed at the 2 locations could not be assessed directly. However, the proportional decline in abundance for all species observed at one site at One Tree Island was greater than the decline observed at either site at Lizard Island, the sites with the more abundant predators (Fig. 1A). Therefore, processes other than predation or predation by other species almost certainly contributed to these declines.

Few studies have used identical methods simultaneously to examine the dynamics of natural communities in different geographic locations. One such study (Dethier \& Duggins 1988) examined the effect of removing chitons on the structure of intertidal communities in Washington and Alaska (USA). Although there were similarities between that experiment and my sampling program (i.e. the spatial scales of sites and locations were similar between these studies), there were many differences. Beyond the obvious temperate versus tropical and intertidal versus subtidal differences between these studies, Dethier \& Duggins (1988) reported very similar species composition and abundance within species at their 2 locations. They also reported very different responses between locations of the communities to chiton removals. In contrast, the fish communities that I studied showed very distinct differences between locations but showed similar responses to experimental disturbances (Caley 1991). Presently, we lack sufficient studies of other communities and locations to begin placing these 2 studies within any comparative geographical or environmental framework.

Total abundance of fishes within these communities fluctuated throughout the year. Abundance was greatest during the summer months at both locations with the minimum abundance observed during the intervening winter. All species of fishes, however, did not show similar temporal patterns, nor were species that did fluctuate seasonally more likely to be from a particular family. Comparative studies of the life histories of these species will be required to understand the sources of these interspecific differences in dynamics.

Pitcher (1988) reported that Pomacentrus nagasakiensis recruited to reefs in the northern section of the Great Barrier Reef earlier in the year than in the southern section. In 4 analyses reported here, differences among censuses were detected. In 3 of these, blennies and gobies, Amblygobius phalaena, and Coris schroederi, seasonal dynamics differed between locations and could be compared to the pattern reported by Pitcher (1988). In the first 2 taxa, peaks and troughs in abundance at Lizard Island (in the northern section) occurred before they occurred at One Tree Island (in the southern section). In the other, C. schroederi, minimum abundance at One Tree Island occurred first. Therefore, these data suggest that a north to south difference in the timing of peak abundances may occur in species other than $P$. nagasakiensis, but also that such a pattern may not be universal. 
In this study I examined patterns of abundance estimated from censuses of reef fish communities at 2 locations separated by $>1000 \mathrm{~km}$. Communities at these 2 locations are composed of different sets of species coexisting under different suites of biotic and abiotic conditions (Caley 1991, this study). While similarities and differences between the fish communities at these 2 locations were detected here, it is inappropriate to generalize these results from location effects to regional effects. In addition, the effects of many characteristics of these 2 locations on the dynamics observed here cannot be addressed. For instance, differences in cross-shelf position (Williams \& Hatcher 1983, Russ 1984) or oceanography may affect community composition and dynamics. Similarly, because of the relatively short length of this study, potentially important among-year differences in abundance can not be discounted. Therefore, in order to narrow the possible causes of the patterns reported here, future studies of regional and large scale temporal effects will need to examine replicate locations within latitudes over longer periods of time. Such studies will be costly and logistically difficult, but they could prove vital to our understanding of how biological communities are organized.

In the meantime, studies such as this can inform us of the similarities and differences between locations at different latitudes. In this case, both spatial and temporal variation in abundance within and between locations was evident, but whether or not a species varied on any particular scale was not predictable from either its taxonomic affiliation or relative abundance. In contrast, however, maximum densities were the best predictor of subsequent per capita declines in abundance irrespective of site, location or taxonomic affiliation. The cause(s) and generality of such density-dependent declines remain to be elucidated.

Acknowledgements. Comments by and discussions with $\mathrm{R}$. Alford, M. Hixon, G. Inglis, L. Schwarzkopf, A. Sheldon and $H$. Sweatman and anonymous reviewers improved this manuscript. Support from the Australian Geographic Society, the Australian Research Council, the Isaak Walton Killam Memorial Fund, the Natural Sciences and Engineering Research Council of Canada, the Royal Zoological Society of New South Wales, the University of Sydney, and the Australian Museum, through a Lizard Island Doctoral Fellowship, made this research possible and is gratefully acknowledged. This paper is a contribution from the Australian Museum's Lizard Island Field Station and the University of Sydney's One Tree Island Field Station and is contribution number 401 of James Cook University Department of Marine Biology.

\section{LITERATURE CITED}

Allen GR (1975) Damselfishes of the South Seas. TFH Publ, Neptune City, NJ

Allen GR (1991) Damselfishes of the world. Mergus, Melle
Booth DJ (1995) Juvenile groups in a coral-reef damselfish: density-dependent effects on individual fitness and demography. Ecology 76:91-106

Caley MJ (1991) Mechanisms of coexistence in communities of coral-reef fishes. PhD thesis, University of Sydney

Caswell $\mathrm{H}$ (1978) Predator-mediated coexistence: a nonequilibrium model. Am Nat 112:127-154

Choat JH, Bellwood DR (1991) Reef fishes: their history and evolution. In: Sale PF (ed) The ecology of fishes on coral reefs. Academic Press, San Diego, p 39-66

Cornell HV (1993) Unsaturated patterns in species assemblages: the role of regional processes in setting local species richness. In: Ricklefs RE, Schluter D (eds) Species diversity in ecological communities. University of Chicago Press, p 243-252

Cornell HV, Lawton JH (1992) Species interactions, local and regional processes, and limits to the richness of ecological communities: a theoretical perspective. J Anim Ecol 61:1-12

Day RW, Quinn GP (1989) Comparisons of treatments after analysis of variance. Ecol Monogr 59:433-463

Dennis B, Taper M (1994) Density dependence in time series observations of natural populations: estimation and testing. Ecol Monogr 64:205-224

Dethier MN, Duggins DO (1988) Variation in strong interactions in the intertidal zone along a geographical gradient: a Washington-Alaska comparison. Mar Ecol Prog Ser 50: $97-1.05$

Doherty PJ (1991) Spatial and temporal patterns in recruitment. In: Sale PF (ed) The ecology of fishes on coral reefs. Academic Press, San Diego, p 261-293

Forrester GE (1990) Factors influencing the juvenile demography of a coral reef fish. Ecology 71:1666-1681

Hanski I, Woiwod I, Perry J (1993) Density dependence, population persistence, and largely futile arguments. Oecologia 95:595-598

Hiatt RW, Strasburg DW (1960) Ecological relationships of the fish fauna on coral reefs of the Marshall Islands. Ecol Monogr 30:65-127

Hixon MA (1991) Predation as a process structuring coral-reef fish communities. In: Sale PF (ed) The ecology of fishes on coral reefs. Academic Press, San Diego, p 475-508

Holyoak M, Lawton JH (1993) Comment arising from a paper by Wolda and Dennis: using and interpreting the results of tests for density dependence. Oecologia 95:592-594

Hunte W, Côté IM (1989) Recruitment in the redlip blenny Ophioblennius atlanticus: is space limiting? Coral Reefs 8: $45-50$

Jones GP (1990) The importance of recruitment to the dynamics of a coral reef fish population. Ecology 71:1691-1698

Jones G.P (1991) Post-recruitment processes in the ecology of coral reef fish populations: a multifactorial perspective. In Sale PF (ed) The ecology of fishes on coral reefs. Academic Press, Sán Diego, p 294-328

Levin SA (1974) Dispersion and population interactions. Am Nat 108:207-228

Mead R (1988) The design of experiments. Cambridge University Press, New York

Myers RF (1989) Micronesian reef fishes. Coral Graphics, Agana, Guam

Pitcher CR (1988) Spatial variation in the temporal pattern of recruitment of a coral reef damselfish. Proc 6th Int Coral Reef Symp 2:811-816

Pulliam HR (1988) Sources, sinks, and population regulation. Am Nat 132:652-661

Randall JE, Allen GR, Steene RC (1990) Complete diver's and fisherman's guide to fishes of the Creat Barrier Reef and the Coral Sea. Crawford House Press, Bathurst, Australia 
Ricklefs R.E (1987) Community diversity: relative roles of local and regional processes. Science 235:167-171

Ricklefs RE, Schluter D (1993) Species diversity in ecological communities. University of Chicago Press

Russ ( ; (1984) Distribution and abundance of herbivorous grazing fishes in the central Great Barrier Reef. II. Patterns of zonation of mid-shelf and outershelf reefs. Mar Ecol Prog Ser 20:35-44

Russell BC (1983) Annotated checklist of the coral reef fishes in the Capricorn-Bunker Group, Great Barrier Reef, Australia. Great Barrier Reef Marine Park Authority, Townsville

Sale PF (1980) The ecology of fishes on coral reefs. Oceanogr mar Biol A Rev 18:367-421

Sale PF (1991) The ecology of fishes on coral reefs. Academic Press, San Diego

Sale PF, Dybdahl R (1975) Determinants of community structure for coral reef fishes in an experimental habitat. Ecology $56: 1343-1355$

Sale PF, Dybdahl R (1978) Determinants of community structure for coral reef fishes in isolated coral heads at lagoonal and reef slope sites. Oecologia 34:57-74

Sale PF, Steel WJ (1989) Temporal variabulity in patterns of association among fish species on coral patch reefs. Mar Ecol Prog Ser 51:35-47

Schluter D, Rjcklefs RE (1993) Convergence and the regional component of species diversity. In: Ricklefs RE, Schluter D (eds) Species diversity and ecological communities. University of Chicago Press, p 230-240

Sokal RR, Rohlf FJ (1981) Biometry. WH Freeman and Co, New York

Springer VG (1982) Pacific plate brogeography, with special reference to shore fishes. Smithson Contr Zool 367:1-182

Stimson JS (1990) Density dependent recruitment in the reef fish Chaetodon miliarı. Environ Biol Fish 29:1-13

This article was submitted to the editor
Sweatman HPA (1985) The influence of adults of some coral reef fishes on larval recruitment. Ecol Monogr 55:469-485

Talbot FH, Gilbert AJ (1981) A comparison of quantitative samples of coral reef fishes latitudinally and longitudinally. Proc 4 th Int Coral Reef Symp, Manila 2:485-490

Talbot FH, Russell BC. Anderson GRV (1978) Coral reef fish communities: unstable, high diversity systems? Ecol Monogr 48:425-440

Thresher RE (1991) Geographic variability in the ecology of coral reef fishes: evidence, evolution and possible implications. In: Sale PF (ed) The ecology of fishes on coral reefs. Academic Press, San Diego, p 401-436

Tupper M. Hunte W (1994) Recruitment dynamics of coral reef fishes in Barbados. Mar Ecol Prog Ser 108:225-235

Underwood A.J, Petraitis PS (1993) Structure of intertidal assemblages in different locations: how can local processes be compared? In: Ricklefs RE, Schluter D (eds) Species diversity in ecological communities. University of Chicago Press, p 39-51

Westoby, M (1993) Biodiversity in Australia compared with other continents. In: Ricklefs RE, Schluter D (eds) Species diversity in ecological communities. University of Chicago Press, p $170-177$

Williams DMcB, Hatcher Al (1983) Structure of fish communities on outer slopes of inshore, mid-shelf and outer shelf reefs of the Great Barrier Reef. Mar Ecol Prog Ser 10 $239-250$

Winer BJ (1971) Statistical principles in experimental design McGraw-Hill Kogakusha, Tokyo

Wolda H, Dennis B (1993) Density dependence tests, are they? Oecologia 95:581-591

Wolda H, Dennis B, Taper ML (1994) Density dependence tests, and largely futile comments: answers to Holyoak and Lawton (1993) and Hanski, Woiwod and Perry (1993). Oecologia 98:229-234

Manuscript first received: August 24, 1994

Revised version accepted: May 19, 1995 